\title{
System of criminal penalties of Russian federation: legal regulation and sentencing practice
}

\author{
Alexandra Brovkina ${ }^{1}$, Victor Vezlomtsev ${ }^{1}$, Svetlana Zakharova ${ }^{1}$, Olga Shuranova ${ }^{1}$, and \\ Yuri Truntsevsky ${ }^{2 *}$ \\ ${ }^{1}$ Academy of Law and Management of the Federal Penal Service of Russia, 390000, 1 Sennaya str., \\ Ryazan, Russia \\ ${ }^{2}$ Institute of Legislation and Comparative Law under the Government of the Russian Federation, \\ 117218, 34 Cheremushkinskaya str., Moscow, Russia
}

\begin{abstract}
The article presents the questions of constructing a system of criminal penalties under the legislation of the Russian Federation, the problems of imposing various types of punishments taking into account the rules for constructing criminal law sanctions. Changes and additions, various types of criminal penalties, including the content of sanctions in the articles, lead to an imbalance in the principles of their construction. The punishment system is currently in need of reform. An analysis of the sanctions of the articles of a special part of the Criminal Code of the Russian Federation revealed inconsistencies with the requirements of legislative equipment in their development, which creates serious difficulties in the appointment of sentences by the courts. Penalties under criminal law sanctions include punishment in the form of punishment, forced labor, imprisonment for a specified period. The legislation does not take into account the nature and degree of threat to crimes committed in the formation of sanctions articles. Criminal law and criminal law protection, and criminal procedural requirements, and punishments. In accordance with the peculiarities of the formation of the punishment system, the creation of criminal sanctions, as well as taking into account the goals of punishment in the domestic criminal law, which allows us to develop recommendations on the preparation of sanctions for articles of the criminal code of the Russian Federation.
\end{abstract}

\section{Introduction}

The system of criminal penalties currently set out in the Criminal Code of the Russian Federation (hereinafter - the Criminal Code of the Russian Federation) is formed throughout the entire period, despite the fact that it proves that its creation and effectiveness are used by disputes among forensic scientists and law enforcement.

*Corresponding author: a.copytowa@yandex.ru 


\section{Review of research literature}

The concept of «system» in the explanatory dictionary of S.I. Ozhegova and N.Yu. Shvedovoy is regarded as: 1) a certain order in the location and connection of actions; 2) the form of organization of something; 3) something whole, representing unity; 4) social structure, form of social structure; 5) a set of organizations identical in their tasks; 6) technical device, design; 7) what has become normal, ordinary, regular.

Consideration of the system of criminal punishments, its following in accordance with the established procedure for certain types of punishments, which are a single set of measures applied to persons found guilty of a crime in order to restore social justice, correct the convicted person and confirm the commission of new crimes.

In relation to the system of criminal penalties, it is necessary to highlight its inherent features. Yu.V. Bochkareva is characterized by a system of punishments through six signs.

Firstly, the punishment system is socially determined, and is expressed in the laws of social development. Secondly, a characteristic feature of the punishment system as a legal phenomenon is a sign of its formal certainty, since it is enshrined in criminal law. The legislator, having formulated a list of types of punishments, implemented a system of basic and additional types of punishments. In addition, an independent system of punishments applicable to minors has been identified. In our opinion, it is advisable to allocate to an independent system the punishments imposed by servicemen for committing crimes against military service.

Thirdly, the punishment system is a certain set of its elements (types of punishments). It can be characterized both as a single-level and multi-level education. Fourthly, the types of punishments as elements of a system form an integral whole, since they have a single object of influence and interaction with each other.

Fifth, the integrity of the system and the unity of its elements is due to the fact that all types of punishments ensure the achievement of the same tasks, as well as the goals of punishment.

Sixth, the punishment system and its constituent elements interact with both the «external environment and other systems of criminal law, for example, other criminal law measures, and with criminal law in general, taken as a system, as well as with state, structure and the dynamics of crime» [1].

A.N. Tarbagaev, considering issues of the punishment system, notes that it has such a feature as the location of the types of punishments within the system in a certain order, when each subsequent punishment is more strict in its punitive content than the previous one [2]. Given the latest changes and additions to the types of criminal punishments, the indicated sign of the punishment system does not look reasonable. This, in our opinion, is also confirmed by the peculiarities of constructing sanctions for articles of the Special Part of the Criminal Code of the Russian Federation.

\section{Results}

Theories of retributivism and consequentialism in understanding the goals of the punishment system. An integral part of sociocultural norms is punishment for violation of norms. Everything related to punishment, and even criminology: it has acquired social significance.

It is necessary to combine into two groups: retaliation (retributivism) and utilitarian (consequentialism). The point is that the punishment should be a guarantee that the punishment should be fair, and the punishment - a fair punishment proportional to the serious image committed. 
One of the main theorists of retributivism is I. Kant [3]. He adheres to the principle of equality. If a person has committed a crime, he will be ready to suffer in this way. Kant calls this the principle of retribution. «... only the right of retribution (ius talionis), if we only understand it as being exercised within the framework of justice ..., can accurately determine the quality and measure of punishment; all other rights are vague and cannot, due to the interference of other considerations, conclude a conformity with a sentence of pure and strict justice». For I. Kant, the justification of punishment is derived from the principle of retribution, which is based on the principle of equality. The concepts of «well-deserved retribution» and «justice» play a central role in Kant's theory, and he excludes the possibility of justifying the punishment of the innocent.

Retributivists believe that, firstly, the punishment should be proportional to the crime (quantitative correspondence) and, secondly, correspond to it (qualitative correspondence).

Proportionality is ensured by the fact that more severe penalties are imposed for more serious crimes. But how to determine which ones? We can build a scale of crimes of varying severity, from the most insignificant to the most serious, and a scale of punishments, from the mildest to the most severe. But this alone will not tell us what specific penalties for specific crimes should be.

The problem is this: talking about who deserves what is possible only in the context of clear rules. But in the field of morality there are no rules that link the gravity of the crime with a certain level of suffering of the offender or a certain duration of imprisonment.

In general terms, all criticism of retributivism can be reduced to the fact that supporters of this theory are not able to give any clear interpretation of the justification of the link between crime and punishment.

The consensus among modern retributivists can be formulated as follows: the main goal of the punishment system should be to guarantee that criminals receive fair retribution and that they will suffer through fair punishment proportional to the seriousness of their crimes. In the 1970s and 1980s, fair retaliation in the United States became the main slogan of the sentencing movement with a specific sentence of imprisonment - a movement that forced the penitentiary authorities in many states and at the federal level to repeal the "fork" laws in prison new sentencing rules aimed at limiting the subjective factor in decisions of the judiciary and ensuring greater objectivity and accuracy in determining the terms of imprisonment.

Recently, these new sentencing rules have been sharply criticized, in particular by judges who stated that the introduction of directive standards on sentencing practices caused them moral damage, depriving them of the prerogative to make fair sentences in specific cases. Despite all these difficulties, many analysts still consider prescriptive sentencing standards and fixed terms of imprisonment as more preferable than the system of generally uncontrolled arbitrariness of judges still used in the UK and other countries. The severity of the verdict must be directly linked to the seriousness of the offense.

Consequentialism is a younger theory of punishment than retributivism, but no less popular. From the point of view of representatives of this theory, the punishment is justified only due to the good results that outweigh the bad ones. The strengths of this theory are primarily that punishment helps prevent crime and a well-designed punishment system can have the effect of correcting criminals. There are also weaknesses in this theory. She uses people as a means to an end, and many consider it morally unacceptable. The main idea of utilitarianism is not supposed to punish only those responsible or limit the degree of punishment to what the offender deserves. If the goal of punishment is to ensure the public good, then this goal will be faster achieved by punishing the innocent. It is also assumed that the public good is easier to achieve through overwhelming punishments: a greater punishment may have a greater deterrent effect. All this is a violation of justice, which retributivism does not allow. 
Guided by the considered concepts (retributivism and consequentialism) in practice, society strives to achieve mutually exclusive goals: at the same time they strive to humiliate and correct criminals, punish, inflict suffering and make them a full-fledged citizen of society. There are also many combinations of them, but, nevertheless, the search continues for a model that could combine the two approaches and not only contribute to the effectiveness of criminal punishment, but also pay due attention to guilt and retribution.

The general conclusion from the analysis of trends in criminal punishment in Russia over the period of its sovereign development is ambiguous. On the one hand, there is a controversial process of democratization of the criminal justice system and the humanization of criminal liability, the expansion of alternative criminal sentences to deprivation of liberty, and their reduction in severity. On the other hand, crime is growing rapidly, more severe and especially severe, and this requires increased responsibility. What the state responds by tightening sanctions for certain types of crimes.

In an effort to improve the system of punishments, the legislator is often carried away either by the humanization of punishments, or vice versa by tightening them. The ongoing reforms have led to the fact that the system of criminal punishments, arranged in increasing order of punitive nature, has been inconsistent.

Historical analysis of the formation of the criminal punishment system. Let us turn to the history of the development of the modern system of criminal punishments in Russia. It began to be formed even before the Criminal Code of the Russian Federation was adopted. The impetus for the revision of the punishment system was the application of Russia to join the Council of Europe and a number of requirements of the international community, including with regard to the humanization of criminal punishments.

This implied that Russia was ready to abandon the death penalty, replacing it with an alternative form of punishment - life imprisonment. Federal Law of December 17, 1992 in Art. 24 of the Criminal Code of the RSFSR of 1960, an indication is included that "when a death penalty is pardoned by imprisonment, it can be assigned for life (part 1)." We note in this case that life imprisonment was not included in the punishment system and could not be appointed by the courts.

The humanization of criminal penalties also implied the existence in the criminal law system of types of punishments not related to isolation from society, the interchangeability of which would allow them to be applied economically in practice. The need to reform the criminal penal system was obvious, and in 1996 the Criminal Code of the Russian Federation was developed and approved, which came into force on January 1, 1997 and is still in force.

At the time of the adoption of the Criminal Code of the Russian Federation in 1996, thirteen types of sentences were fixed in the punishment system, such as: a) a fine; b) deprivation of the right to occupy certain positions or engage in certain activities; c) deprivation of a special, military or honorary title, class rank and state awards; d) compulsory work; e) correctional work; f) restriction on military service; g) confiscation of property; h) restriction of freedom; i) arrest; j) maintenance in a disciplinary military unit; k) imprisonment for a fixed term; l) life imprisonment; $m$ ) the death penalty.

The introduced system included a number of new types of punishments for Russia that were not related to isolation from society: compulsory work, restriction of military service, restriction of freedom. The types of punishments associated with the isolation of the person who committed the crime from society were supplemented by arrest and life imprisonment, which received the status of an independent type of punishment.

On the one hand, the humanization of punishment and its application was recognized as a priority area of improving the mechanism of legal regulation in the state policy of combating crime. On the other hand, the aggravation of the criminal situation in Russia, associated with the repeated increase in general and special crime, led to an increase in the 
intensity of criminal repression, which was reflected in a rather significant increase in prison sentences: their upper limit increased to 20 years, and reached 25 years, and with a combination of sentences - 30 years.

In December 2003, confiscation of property was excluded from the list of punishments, which in July 2006 the legislator reintroduced into the Criminal Code of the Russian Federation, but as a different measure of a criminal law nature. However, a number of researchers of the problems of modern criminal law advocated its preservation (A.I. Zubkov, A.N. Ignatov, N.F. Kuznetsova), indicating that this type of punishment can serve as an effective way to combat corruption and organized crime [11].

The arrest by the courts, introduced in 1996 as the main form of punishment, does not apply due to the lack of arrest houses in which it must be executed. Therefore, if the sanction contains articles of the Special Part of the Criminal Code of the Russian Federation, along with other types of punishments imposed for committing a crime, arrest, we cannot consider it as an alternative type of punishment due to the impossibility of its appointment and execution. To date, this type of punishment can only be applied to military personnel in accordance with Part 3 of Art. 54 of the Criminal Code of the Russian Federation, serving him at the guardhouse. Another question arises regarding the terms of arrest - from one to six months. At its core, arrest is complete isolation from society, that is, it essentially refers to one of the urgent types of imprisonment with strictly defined terms. But the content of term imprisonment sets a minimum sentence of two months (part 2 of article 56 of the Criminal Code of the Russian Federation). These two types of punishment should complement each other, but not interchangeably. Indeed, in the case of sentencing in the form of arrest for 6 months, and imprisonment from 2 to 6 months - the severity of the latter can be challenged. Therefore, in our opinion, it is necessary to establish terms for imprisonment from 6 months to 20 years, in order to avoid confusion in the degree of severity of sentences. We also believe that due to the lack of arrest houses, make arrest a special type of punishment and, along with restrictions on military service, and maintenance in a disciplinary military unit, apply it only to military personnel.

In December 2011, the legislator included forced labor in the punishment system, attributing them to the main type of punishment. At the same time, in part 1 of Article 531 of the Criminal Code of the Russian Federation, it is stipulated that forced labor is used as an alternative to imprisonment for committing crimes of minor or medium gravity or for committing a serious crime for the first time, provided that this type of punishment is fixed in the sanctions of articles of the Special Part of the Criminal Code of the Russian Federation and sentencing in the form of imprisonment for a term not exceeding five years [12].

Currently, the criminal punishment system is as follows:

1) a fine; 2) deprivation of the right to occupy certain positions or engage in activities; 3) deprivation of a special, military or honorary title, class rank and state award; 4) compulsory work; 5) correctional work; 6) restrictions on military service; 7) restriction of freedom; 8) forced labor; 9) arrest; 10) maintenance in a disciplinary military unit; 11) imprisonment for a fixed term; 12) life imprisonment; 13) the death penalty.

On April 16, 1997, Russia signed Protocol No. 6 on the protection of human rights and fundamental freedoms regarding the abolition of the death penalty (in peacetime). The State Duma was to ratify it before May 1999. Despite the fact that the 6th Protocol was never approved by all member states of the Council of Europe, the death penalty in Russia is permitted in accordance with the Vienna Convention. before ratification. 


\section{Discussion}

An analysis of the summary statistical information on the state of a criminal record in Russia from 2014 to the first half of 2019 allows us to decide that the punishment should be imposed in accordance with the current punishment, as well as conditionally sentenced for an explicit punishment (over 50\% from all assigned punishments). Second place, beginning in 2016 , is occupied by compulsory work (16-19\%). The third place belongs to the fine as the main form of punishment (11-15\%). Correctional work (7-10\%) is in fourth place in the frequency of appointment. Restriction of freedom takes the main place $(2-3.5 \%)$. The remaining share falls on the remaining types of punishments (see Table 1).

All of the above makes it necessary to develop problems of systematizing criminal penalties and improving the design of sanctions for articles of the Special Part of the Criminal Code of the Russian Federation.

Considers the systematization of criminal sentences Yu.V. Bochreva, notes that the punishment requires that the criminal law system and criminal law acts in practice. a list of the basic necessary properties: interconnection, interdependence, organizational unity and other components inherent in system education [2]. We support her position on this issue. The current criminal punishment system can hardly be called consistent. Such a feature of the system as built in a certain order, depending on the severity of the punishment.

A.N. Tarbagaev emphasizes that after May 4, 2011 No. 97-Ф3 and July 14, 2012 No. 141- $\Phi 3$, the minimum and maximum fines determined in accordance with the amount were increased to 5 thousand and 5 million, respectively. punishments are commercial bribes or bribes, as opposed to penalties [3]. This means that the punishment should be strictly defined, and the punishment should be limited. 1 tbsp. 53 of the Criminal Code, for a period of 2 months to four years.

Consideration of the system of criminal penalties in the design of sanctions for articles of the Special Part of the Criminal Code of the Russian Federation. Criminal legal sanction in the theory of criminal law is considered as an instrument of state influence on a person, it provides a measure of state coercion, which can be applied to a person who committed a crime and violates the law $[13,14]$.

As a rule, a criminal legal sanction is formed by including various types of punishments (basic and additional) in it and establishing their size (the limits within which it is possible to choose the amount of punishment). Currently, only relatively specific sanctions are formed in the criminal legislation of the Russian Federation, which indicate the type of state coercion (type of punishment) and its possible size. A relatively specific sanction can be alternative (complex) and non-alternative (simple). An alternative sanction gives the law enforcer the choice of one basic punishment from several presented in its content.

Alternative sanctions can be divided into two subspecies: sanctions with imprisonment and sanctions not involving imprisonment $[15,20]$.

We analyzed the sanctions of the articles of the Special Part of the Criminal Code of the Russian Federation, which allowed us to establish certain laws of their formation.

A special part of the Criminal Code of the Russian Federation contains 938 corpus delicti, of which only 96 do not provide for sanctions in the form of imprisonment (about 10\%). 266 convictions provide for a single sentence of imprisonment (approximately 28\%). The sanctions of 109 offenses provide as an alternative two types of punishment: forced labor and imprisonment for a certain term (about 12\%). In the course of the analysis, 7 corpus delicti were revealed for which the legislator provides for forced labor, along with other types of punishments, in an alternative sanction, but there is no possibility of imposing a sentence of imprisonment in the sanction. Based on the content of Article 531 of the Criminal Code, forced labor can be used as an alternative to imprisonment. This fact indicates violations of the legislative technique in the construction of sanctions for articles 
of the Special Part of the Criminal Code of the Russian Federation. When regulating sanctions on the possibility of applying forced labor, the legislator should automatically provide for deprivation of liberty as an alternative punishment, otherwise the possibility of appointing forced labor is excluded.

Table 1. Punishments imposed for committing a crime

\begin{tabular}{|c|c|c|c|c|c|c|c|c|c|c|c|c|c|c|}
\hline \multirow[b]{2}{*}{ 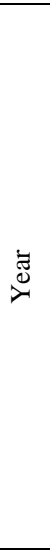 } & \multirow[b]{2}{*}{ 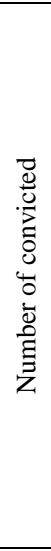 } & \multicolumn{13}{|c|}{$\begin{array}{c}\text { Types of basic punishments imposed for committing a crime, and the number of persons convicted } \\
\text { of them [18] }\end{array}$} \\
\hline & & 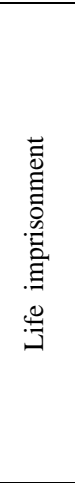 & 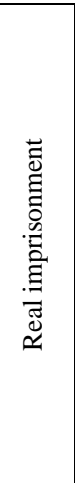 & 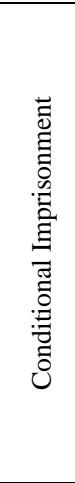 & 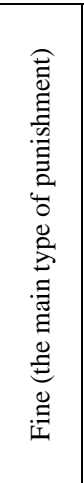 & 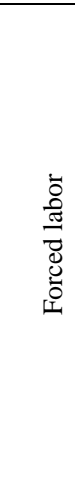 & 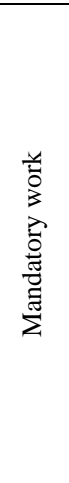 & 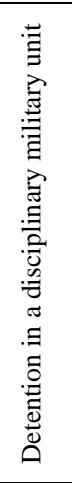 & 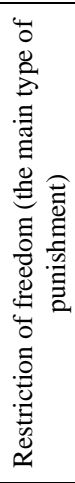 & 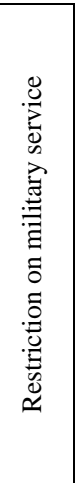 & 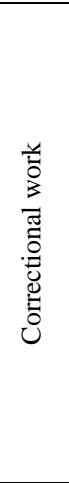 & 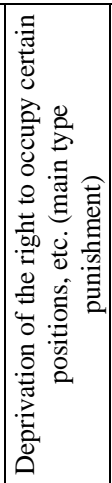 & $\stackrel{\overrightarrow{3}}{\stackrel{2}{2}}$ & 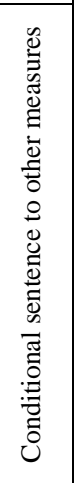 \\
\hline 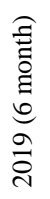 & $\begin{array}{l}\text { हैं } \\
\overline{\text { ते }}\end{array}$ & $=\begin{array}{l}0 \\
0 \\
0 \\
0\end{array}$ & 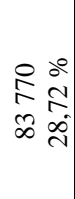 & 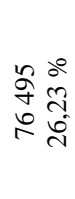 & 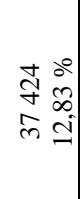 & 总总 & 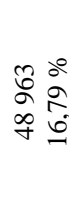 & $\begin{array}{ll}0 \\
0 \\
ㅇ \\
0 \\
0 \\
0\end{array}$ & $\begin{array}{l}\hat{8} \\
0 \\
0 \\
0\end{array}$ & 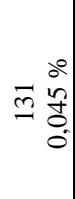 & 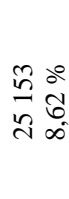 & 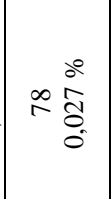 & ' & $\begin{array}{ccc}0 & 0 \\
\infty & 0 \\
i & -i\end{array}$ \\
\hline$\stackrel{\infty}{\stackrel{i}{\pi}}$ & $\begin{array}{l}\overline{\hat{\lambda}} \\
\infty \\
\hat{b}\end{array}$ & in & 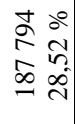 & $\begin{array}{l}0 \\
0 \\
0 \\
0 \\
0 \\
0\end{array}$ & $\begin{array}{lll}8 & 0 \\
2 & 0 \\
n & 0 \\
\infty & 0\end{array}$ & $\stackrel{2}{2} \frac{\circ}{0}$ & $\begin{array}{ll}\infty & 0 \\
0 & \delta \\
0 & 0 \\
0 & = \\
= & =\end{array}$ & \& $\frac{\circ}{0}$ & 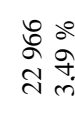 & $\stackrel{\infty}{\infty} \stackrel{\substack{0 \\
0}}{0}$ & \begin{tabular}{l} 
立。 \\
\multirow{4}{*}{$\infty$} \\
is
\end{tabular} & $\ddot{\infty} \stackrel{\infty}{\infty}$ & n $n \begin{array}{l}0 \\
8 \\
8 \\
8 \\
0 \\
0\end{array}$ & 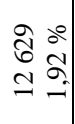 \\
\hline$\overline{\vec{i}}$ & $\begin{array}{l}\text { to } \\
\text { ô } \\
\hat{\delta}\end{array}$ & ni $\begin{array}{l}\delta^{\circ} \\
0 \\
0\end{array}$ & 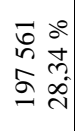 & 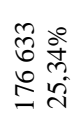 & 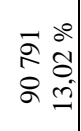 & \& & 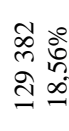 & $\approx \frac{50}{5}$ & 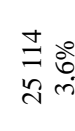 & $\stackrel{\substack{0 \\
\stackrel{0}{0} \\
0}}{0}$ & 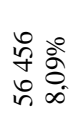 & $\stackrel{\stackrel{0}{\sim}}{\stackrel{0}{0}}$ & n $\begin{array}{r}0 \\
8 \\
8 \\
0 \\
0\end{array}$ & $\begin{array}{ll}m & 0 \\
\infty & \pm \\
\simeq & \infty \\
\simeq\end{array}$ \\
\hline$\stackrel{\circ}{\stackrel{2}{\sim}}$ & $\begin{array}{l}\text { ले } \\
\text { से }\end{array}$ & $\infty \stackrel{\circ}{\frac{\delta}{0}}$ & 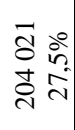 & 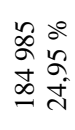 & $\begin{array}{ll}\hat{\sigma} & 00 \\
8 & n \\
8 & n \\
8 & 0\end{array}$ & $\begin{array}{r}\circ \\
+ \\
+ \\
8 \\
8 \\
0\end{array}$ & 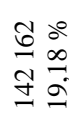 & $\bar{I} \stackrel{8}{0}$ & 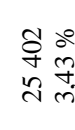 & 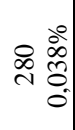 & 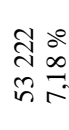 & તి & $\begin{array}{r}0 \\
0 \\
0 \\
0 \\
8 \\
0 \\
0\end{array}$ & $\begin{array}{ll} \pm & 0 \\
i n & \infty \\
m & \infty \\
-\infty\end{array}$ \\
\hline$\frac{n}{2}$ & $\begin{array}{l}\hat{8} \\
\text { }\end{array}$ & n̊ & 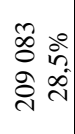 & 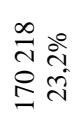 & $\begin{array}{ll}0 & 0 \\
\infty & 0 \\
\infty & 5 \\
\infty & 0 \\
\infty & =\end{array}$ & $\begin{array}{r}\circ \\
\text { N } \\
\delta \\
0 \\
0\end{array}$ & 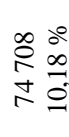 & \& & $\begin{array}{ll}0 & 0 \\
\infty & 0 \\
0 & 1 \\
0 & 0 \\
0\end{array}$ & ¿ุ & 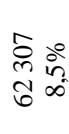 & 芩 & 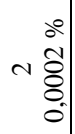 & $\begin{array}{ll}\infty & 0 \\
\infty & 0 \\
n & 0 \\
- & 0\end{array}$ \\
\hline$\stackrel{\vec{\sim}}{\stackrel{d}{*}}$ & $\begin{array}{l}\stackrel{n}{\rho} \\
\stackrel{2}{2} \\
\stackrel{2}{R}\end{array}$ & గু & 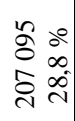 & 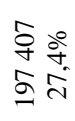 & \begin{tabular}{ll}
8 & 0 \\
0 & 0 \\
\hdashline & 0 \\
$=$ & 0
\end{tabular} & ' & 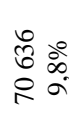 & $\stackrel{\infty}{\stackrel{\infty}{8}} \stackrel{8}{0}$ & 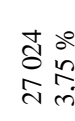 & \begin{tabular}{cc}
$\stackrel{0}{0}$ \\
$\stackrel{4}{4}$ \\
\hdashline \\
0
\end{tabular} & $\begin{array}{l}\hat{\sigma} \stackrel{\circ}{0} \\
\hat{2} \\
\hat{0}\end{array}$ & ते & $\hat{\sim} \begin{array}{l}0 \\
0 \\
0 \\
0\end{array}$ & $\begin{array}{ll}n & 0 \\
n & 0 \\
0 & 0 \\
i & 0\end{array}$ \\
\hline
\end{tabular}

Of particular interest, with respect to the criminal punishment system, are the convictions for which the legislator provides as an alternative: fines, forced labor and 
imprisonment for a fixed term (211 convictions, which is $22.5 \%$ ). If we take into account that the punishment system is structured in a manner where each subsequent punishment is more stringent in its punitive content than the previous one, then the logical question arises as to why the legislator provides for the commission of a crime initially with the "mildest" penalty in the form of a fine, and then actually the most strict types of punishment - forced labor and imprisonment for a certain period. Apparently, the current system of punishments does not correspond to this attribute.

The legislative practice of constructing sanctions for articles of the Special Part of the Criminal Code of the Russian Federation indicates the lack of a clear understanding of the legislator about the principles for selecting the main types of punishments for alternative sanctions, as well as the peculiarities of the formation of single sanctions $[16,18]$.

\section{Conclusion}

Summarizing the data on the influence of the object of the crime on the process of constructing sanctions, we highlighted the pattern according to which the main share of crimes against the peace and security of mankind and human life are punishable by deprivation of liberty for a fixed term or life imprisonment. The same applies to multiobjective crimes, in which one of the objects is human life. In our opinion, the legislator is attempting to develop a uniform system for constructing sanctions depending on the nature and degree of public danger of the crime committed, however, these attempts cannot always be considered successful.

At the moment, neither theory nor practice have a clear, scientifically sound system for constructing criminal law sanctions. In general, agreeing with the opinion of E.V. Gustovoi, we note that when constructing sanctions, the legislator should adhere to the following sequence of actions:

- determination of the nature and degree of public danger of the crime committed;

- determination of the immediate object depending on its social significance;

- creating a hierarchical system (categorization) of crimes based on the significance of the main immediate object and the social danger of the crime;

- building a system of model sanctions for each category of crimes $[17,19]$.

E.V. Gustova reduces the dependence of the construction of alternative (non-alternative) model sanctions on the category of crime. It looks like this:

a) sanctions establishing criminal liability for crimes of minor gravity, in her opinion, should be only alternative. In this case, two varieties of alternative sanctions are possible: 1) without deprivation of liberty as part of an alternative; 2) with a downward alternative.

b) sanctions establishing criminal liability for crimes of medium gravity should only be alternative with a downward alternative.

c) sanctions establishing criminal liability for serious crimes can be either nonalternative, providing only imprisonment, or alternative with a downward alternative.

d) sanctions establishing criminal liability for especially serious crimes can be both nonalternative, providing only imprisonment, and alternative with a boosting alternative [17].

However, such an algorithm seems erroneous to us, since the legislator in article 15 of the Criminal Code of the Russian Federation, defining categories of crimes, correlates the form of guilt and the maximum amount of punishment in the form of imprisonment for committing an act. In fact, this is the reverse process of determining the gravity of the crime, based on the assigned punishment for its commission.

Summing up the study, we emphasize that the current system of criminal punishment needs to be adjusted. The hierarchy of the types of punishments must be changed. Fine currently cannot be recognized as the mildest type of punishment. A change in the system of criminal penalties will entail a change in the sanctions of articles of the Special Part of 
the Criminal Code of the Russian Federation. In this case, it is necessary to formulate a reasonable algorithm for the construction of criminal sanctions.

\section{References}

1. Yu. V. Bochkareva, Problems of improving the system of punishments in the criminal legislation of the Russian Federation 3, 13-14 (2009)

2. A. N. Tarbagaev, Criminol. J. Baikal St. Un. Econ. Law 4, 75-82 (2014)

3.I. Kant, Fundamentals of the metaphysics of morality, (1999)

4.S.I., Ozhegov, N.Yu. Shvedova Explanatory Dictionary of the Russian Language: 80,000 words and phraseological expressions, (2006)

5.V.E. Vezlomtsev, Socio-philosophical analysis of punishment: retributivism and consequentialism, (2010)

6. N. Kuznetsova, Crim. Law. 1, 26-27 (2004)

7.E. S. Shuba, High. Sch. 7, 44 (2016)

8.E. S. Shuba, Act. Iss. Fight ag. Crim. 2, 23-25 (2016)

9.D. Izvin, V. Lez'Er, A. Kopytova, MATEC Web of Conferences 170, 01065 (2018) DOI: $10.1051 /$ matecconf/201817001065

10. Kopytova, MATEC Web of Conferences 106, 08056 (2017) DOI: $10.1051 /$ matecconf/201710608056

11. U. Filatova, N. Semeryanova..et al., 2019, E3S Web of Conferences 91,08064, DOI: $10.1051 / \mathrm{e} 3$ sconf/20199108064

12. M. Gravit, O. Zybina, A. Vaititckii, A. Kopytova, IOP Conference Series: Earth and Environmental Science 90 (1), 012103 (2017) DOI: 10.1088/1755-1315/90/1/012103

13. A.V. Kopytova, N.S. Zotkina, I.G. Reshetnikova, MATEC Web of Conferences 239, 04012 (2018) DOI: 10.1051/matecconf/201823904012

14. V. Lez'Er, , N Semerianova,. Et al. E3S Web of Conferences 2019, 110,02094, DOI: $10.1051 /$ e3sconf/201911002094

15. U. Filatova, N. Semeryanova..et al. 2019, E3S Web of Conferences 91,08071, DOI: $10.1051 / \mathrm{e} 3$ sconf/20199108071

16. R. Kolobov, U. Filatova, et al. E3S Web of Conferences 2019, 110,02095, DOI: $10.1051 / \mathrm{e} 3$ sconf/201911002095

17. N. Semeryanova., O. Fedorenko,. A .Kopytova,. 2018, MATEC Web of Conferences 239,04013, DOI: 10.1051/matecconf/201823904013

18. N. Semeryanova, A Kopytova, L.Dolnikova, V. Morozkov, 2019, MATEC Web of Conferences 239,04008, DOI: 10.1051/matecconf/201823904008 